\title{
The Overlap of International Responsibility of Individual and State for Genocide
}

\author{
Hilda Rezaee ${ }^{1} \&$ Sadegh Salimi ${ }^{2}$ \\ ${ }^{1}$ Ph.D. Candidate of Public International law, Department of Public \& International Law, College of Law and \\ Political Science, Science and Research Branch, Islamic Azad University, Tehran, Iran \\ ${ }^{2}$ Visiting Professor, Department of Public \& International Law, College of Law and Political Science, Science \\ and Research Branch, Islamic Azad University, Tehran, Iran \\ Correspondence: Hilda Rezaee, Department of Public \& International Law, College of Law and Political Science, \\ Science and Research Branch, Islamic Azad University, Tehran, Iran. E-mail: hildar8922@gmail.com
}

Received: Januray 1, 2016 Accepted: Januray 19, 2016 Online Published: February 28, 2016

doi:10.5539/jpl.v9n1p65 URL: http://dx.doi.org/10.5539/jpl.v9n1p65

\begin{abstract}
This study examines the overlap ofinternational responsibility of individual and state for genocide. To describe this overlap, the material and psychological elements of genocide are discussed. International criminal law with the distinction between "ordinary state responsibility" and "aggravated state responsibility " drawing the latter offences beyond the State's international responsibility that is mainly focused on the principle of compensation and in which punitive sanctions are not relevant. The result of this change is the establishment of individual criminal responsibility, and aggravated state responsibility.

The goal ofthe research is to Explain The Overlap of international responsibility of individual and state for genocide to argue that the two items are not two separate categories and rather, they complete each other. so that responsibility of individual and state for the same action following primarily, individual criminal responsibility and exclusively, Bring theaggravated state responsibility.
\end{abstract}

Keywords: the overlap of material element, the overlap of psychological element, aggravated state responsibility, individual criminal responsibility, genocide

\section{Introduction}

Event of collective crimes, is not considered as a new event on the international stage, therefore, in the international criminal law, like other branches of international law, the obligations and responsibilities of states and people are specified. International criminal law provides, prohibition of international crimes, regardless of the immunities known for people in traditional international law, imposing responsibility for the actions and behavior and therefore, the principle of "individual criminal responsibility" is the most prominent feature of international criminal law. On the other hand, due to sovereignty in international law, states in violation of international obligations have responsibilities. But the issue of "aggravated state responsibility," which is different from liability for ordinary offences of the state, one of the international crimes is genocide.

In general, international responsibility is naturally after the "international obligation". Because of legal and temporal priority, "primary rules" of international law are distinguished from "secondary rules". In other words, "international obligations" that are caused by the common law or treaties are the "primary rules" and the rules governing the consequences of violation of an international obligation are the rules related to the international responsibility of states in the "secondary rules". For this reason, the second part of Article 2 of the International Law Commission's draft on international responsibility of states (2001) provides that violations of "international obligation" by state is subject to international responsibility. As violations by state, states are responsible for compensation and the payment of compensation to the state that was damaged in case of the "international wrongful act" in international law. Thus, the responsibility of state for violations of its international obligations is restricted to "compensation" in the form of"restitution", "compensation" or "satisfaction".

Historically, upon the end of World War II and the beginning of a new season in support of international law, the international responsibility of states saw special developments, so that the term "new era of responsibility of international organizations" was created. One reason for this change is the addition of two new categories of 
crimes, "crimes against peace" and "crimes against humanity" to the previously recognized crimes.

In the days following World War II and in 1945, the Nuremberg Tribunal and the Tokyo Tribunal launching the trial of war criminals and ignoring the principle of individual criminal responsibility in the light of the immunity of senior state officials, sought the implementation of the principle of criminal responsibility of state, but what happened was the prosecution of individuals rather than the state, which resulted in neglecting the international responsibility of the state.

Given this situation, the United Nations General Assembly passed on 21 November 1947, a resolution 177 (II) and asked the International Law Commission to prepare Code of offences Against the peace and security of mankind. Finally, the Commission presented its report on 25 April 1950. The report, referring to Resolution 95 (1) dated 11 December 1946 of the General Assembly that the United Nations Charter and the Statute of the Nuremberg Tribunal are indicative of the principles of international law, drew a distinction between the concept of "crimes against peace and human security" and "international crimes". The report noted that "individual criminal responsibility in international law is a principle emphasized in the provisions of international criminal law and the statutes of the criminal courts, but it is doubtful whether the individual criminal responsibility should be defined as a responsibility of state as well."

Finally, the Commission stated that:

"We cannot attribute a separate responsibility to organizations and state in addition to individual criminal responsibility. Because different international treaties have not provided for such state's responsibility and the Statute of Nuremberg is also one of the multilateral international instruments. "

Unlike the 1950 report of the International Law Commission of the Nuremberg Tribunal, in 1980 draft on the initiative of the international responsibility of states, in Article 19, entitled "International crimes and international crimes of state", the "international crimes of states" were recognized.

According to paragraph 2 of this article, "If the international violation by state results from a breach of an international obligation while necessity of observance of the same is so much that violation thereof is recognized as crime by the international community in general, the said offense shall be an international crime."

Article 1 of International Law Commission Draft (2001) on The Responsibility of states, states that: "Every internationally wrongful act of a state entails the international responsibility of that state"and paragraph 1 of article 40 of the draft provides that: "This chapter applies to the international responsibility which is entailed by serious breach by a state of an obligation arising under a premptory norm of general international law". The paragraph 2 of this article also states: "A breach of such an obligation, is serious if it involves a gross or systematic failure by the responsible state to fulfill the obligation."

According to the above said, since the provisions of international criminal law governing criminal liability are limited to the people, for this reason, one of the basic principles of international criminal law is the principle of "individual responsibility". On the other hand, some obligations in international criminal law are within the scope of the obligations of states are, such as a commitment to legislation or obligation to prevent crimes such as genocide, thus exclusion of the state from the responsibility is this area of international law is inconceivable and a kind of parallel responsibility with individual criminal responsibility can be considered for the aggravated responsibility of the state.

\section{The Material Element of Genocide}

Definition of genocide doesn't consider a special program for the destruction of a protected group as being among elements of the crime. However, given the definition requires full or partial destruction of the target group, it is naturally a mass crime. But, of course, such a criminal purpose is achieved only if the perpetrator of the crime is also a group. However, despite historical commission of genocide by groups or state, its collective nature is not considered in the definition in terms of number of criminals. From view of responsibility of state, it also applies and although draft provisions of state liability don't stipulate any such severity, according to international law commission, genocide in itself is violation of responsibility to international community.

However, this does not mean that the participation of a state agency in genocide is enough to bring about aggravated responsibility, such acts involve genocide if they are done through a widespread state practice. Of course, there's no denying of the ordinary responsibility of state for such acts. For example, if state A commits genocide with the participation of official agency B, state A is subject to aggravated responsibility, and the state $\mathrm{B}$ incurres a charge of ordinary liability, and the state will just normal responsibilities. But can genocide be defined in a way that it has a collective character and requires establishment of substantial contribution of the state agency and therefore doesn't involve serious violation under Article 40, Approaches as regards collective 
nature of genocide in international criminal law are different. As mentioned earlier, holding people liable for genocide doesn't require proof of genocidal policy or committing a prohibited act by a group of criminals, and even a single person can destroy a target group.

\subsection{Jelisic Case}

In Jelisic case, murder committed by defendant was enough to establish material element of the crime of genocide. Invoking the preparatory works of the 1948 Convention in which after the notification by Special Committee in the drafting, premeditation was not considered as a legal element of genocide, the court concluded that drafters of convention didn't consider the existence of an organization or system acting for the purpose of genocide as legal element and accordingly they didn't rule out a person seeking to destroy a group. It seems that nature and purpose of international criminal law that is based on individual liability is the reason for interpretation of genocide in way to include cases involving individual criminals.

\subsection{Darfur Case}

Darfur's case, the most obvious example of the possibility of adopting two contradictory approaches to individual and state responsibility for the crime of genocide. According to the Commission, there has no policy based on genocide by state and target of the state of Sudan and militias under its control from committing crimes against humanity and the physical destruction of the target group were not related. However, the Commission only established individual criminal responsibility and in different terms, despite the participation of Sudanese institutions in crime, aggravated responsibility of state was rejected. The commission "did not consider as impossible the intention of genocide of some state officials" and established their criminal liability for genocide as being the competency of judicial authorities due to lack of participation of Sudan. As we shall see, it is difficult to accept this the opposite approaches, especially about establishing mental element.

\subsection{International Criminal Tribunal for Rwanda (ICTR)}

In the first judicial procedure of Criminal Tribunal for Rwanda, which was devoted mainly to Genocide crime, defendant's personal behavior was considered regardless of the association with the genocidal state policy. However, court proceedings considered genocide in addition to the actions leading to genocide (because they are part of the broad framework of genocide), but in this case, proof of genocide in Rwanda and accusation of participation in it was considered essential for prosecution. As mentioned in the case of crimes against humanity, this approach allows the court to establish individual responsibility based on the general framework of collective responsibility and individual criminal behavior.

However, a different procedure was adopted by Rwanda Criminal Court's jurisdiction and judicial proof indicating genocide Rwanda was used. In this case, Appeals Chamber rejected the Trial Chamber's approach (according to it, the court should only consider the defendant's personal contribution to Genocide), and acknowledged that genocide made in Rwanda, which occurred in 1994, was a crime that was committed at the collective level and the importance of the general framework for understanding the individual acts of criminal behavior and establishing individual criminal responsibility (not only about Genocide but also about other crimes, including crimes against humanity) was stressed. So, there is no need for prosecutors to convict the accused to prove the criminal behavior in which he participated by doing separate acts. By adopting this approach, since the mass criminal phenomenon is established, and then the individual responsibility of those who participated in the operation of genocide is established, it is difficult to deny aggravated responsibility of state.

To consider the collective nature of genocide, there is also an indirect method. Proof of specific intention of genocide (to destroy the target group) is hard when genocide is not done preplanned, therefore, national and international criminal tribunals have inferred specific malice fromreal evidence, particularly systematic or widespread violations. However the overall framework of criminal behavior can play an indirect role in establishing individual criminal responsibility. In the following, genocide be examined.

\section{The Psychological Element of Genocide}

Genocide requires "intent to destroy, in whole or in part of a national, ethnic, racial or religious group by the defendant." Although legal proceedings of genocide cite statistics to prove intent, but because the mere knowledge is not enough, there may be difficulties. Criminal Tribunal for the former Yugoslavia in the case of Jelisic decreed that "if the defendant's intent to destroy a part of or all of the group cannot be established, even if he is the total or partial destruction involved his knowledge".

However, intent of genocide must be inferred from personal behavior of accused (such as" words, actions or deliberate pattern of behavior that targets victims due to membership of a group while excluding other members). For example, Rwanda Criminal Court in the famous case of media charged the Nahimana, Bartayagoiza and 
Ngozi of leadership, establishing and control of Rwandan media that promoted ethnic messages and called to violence against the Tutsi population.

However, the proof of specific intention of genocide is not always easy, and "in practice the proof of it can be hard if the crimes committed are widespread and not backed by military or organization". This requires that an important role is attached to the general framework for establishing the specific intent of genocide. It is clear from Rwanda Criminal Court's decision in the case of Akayesu. Trial Chamber of the court, in the case, inferred intent of genocide from other acts that are carried out systematically against the same group (whether they are committed by the same offender or even unknown persons).

Trial Chamber of the court considered as effective factors such as the "scale of atrocities committed, their totality, they are being in a region or a country, deliberately and systematically targeting victims because of their membership in a particular group (with the exception of members of other groups) " in the inferring intent of genocide, but the problem here is not limited to this, and in the case of Krstić, the defendant's criminal intent was inferred from collective behavior of persons other than the accused, even unknown entities, as well as from acts which in themselves do not lead to genocide (such as the deliberate destruction of mosques and houses belonging to members of the target group). According to the judgment:

"Trial Chamber is aware that the Convention should be interpreted based on "the principle of legality of crime". Therefore, the Chamber accepts that customary international law, despite recent progress, has limited physical or biological definition of genocide to actions that would destroy all or part of their group. Therefore, nations that attack just cultural or sociological characteristics of a human being group in order to destroy those elements that are specific and distinct from the rest of society does not fit the definition of genocide. However, the Trial Chamber points out where the physical or biological destruction done, often in the form of cultural and religious property and symbols of the group at the same time, attacks as well as physical evidence of the intent to destroy the group. Therefore, the Trial Chamber in this case considered the deliberate destruction of mosques and houses belonging to members of the group as evidence of intent to destroy the group."

However, it seems that although Genocide policy is not legal element Genocide crime, but can be as one of the elements of establishing this criminal act as collectively done in establishing mental element and "the reasons are linked through a plan or policy makes it easier to prove the crime. "Other factors include widespread acts aimed against target groups.

\subsection{General Framework of Criminal Behavior}

For showing respect to the general principles of international criminal law at large, international courts have been very cautious according to the general framework of criminal behavior and only in cases where the intent of genocide is supported by "direct evidence" (including the defendant's personal behavior, statements and also his involvement in acts leading to genocide) they have inferred it from "deliberate pattern of behavior", thus the general rule of individual fault is preferred and second method is used only given hardness of proof of genocide. The way in which the defendant's personal behavior is considered in the light of the overall framework of genocide (program or policy of genocide at the time stated in the indictment). In the following, comparative analysis of decisions of Criminal Court for the former Yugoslavia and Rwanda Criminal Court will be discussed.

As for role of the general framework of criminal behavior in genocide, in the case of Rwanda, the court inferred from case of Akayesu the event of genocide of the Tutsi ethnic group, and further establish the accused's specific intent of genocide. Criminal Tribunal for the former Yugoslavia also adopted a similar approach in the case in July 1995 in Srebrenica Genocide of Blažević and subjected establishment of the legal conditions for participation in genocide to it, while the overall framework of criminal behavior in the conflict in the Balkans (compared with Rwanda) are not indicative of genocide and therefore, the operation of ethnic cleansing in the former Yugoslavia genocide was controversial. This make it hard to establish intentional genocide of defendants for court, and in the end, the court did not establish the intent of genocide.

\subsection{Special Court Precedent}

Special courts legal proceedings can be divided into three groups in terms of intent of Genocide: (1) failure to establish the general framework of criminal intent; (2) establish a framework conducive to Genocide without intentional Genocide of the charged; (3) establish the overall framework and plan of genocide of charged.

\subsubsection{International Criminal Tribunal for the Former Yugoslavia (ICTY)}

Most cases of genocide in Criminal Court for the former Yugoslavia are in the first group. Especially in the case of krajisnik and Brdanin, despite the defendant had a discriminatory intent he had no intent of genocide. In krajisnik case, the Criminal Court for the former Yugoslavia examined intent of genocide of perpetrators of 
related material crimes and considered prosecutor unable to prove them.

Blagojevic and Jokic are among the second group in which despite event of genocide, intent of genocide of defendants was not established and only Blageojevic was charged with assisting genocide.

In accordance with the decision, for an individual action to be described as abetting, the presence of the knowledge of the intention of genocideof main perpetrators is enough. Krstic case is more complex, the Appeals Chamber reversed the Trial Chamber's decision that the joint intent of genocide of krstic and other abettors involved in the joint act is established. Because, in the court's opinion, knowledge by defendant of the presence of plan for genocide is not enough to derive that his abetting the main perpetrators.

\subsubsection{International Criminal Tribunal for Rwanda and the Case of Rutaganda}

In the third group are cases in which the intention of genocide is established based on the wider framework of criminal behavior. As previously mentioned, the Criminal Court for Rwanda, in most cases establishes intent of genocide based the defendant's personal behavior and not only the perception of the general genocide. However, there were cases in which the general framework is of the fundamental role for Criminal Tribunal for Rwanda. For example, the Appeals Chamber in the case Rutaganda wrote:

"No appeal applicant has been found guilty based on theories of" guilt by membership in the group ". Trial Chamber under paragraph 399 votes based on specific acts of Appellant (direct participation in the mass slaughter of Tutsis and being member of the organization and assisting in committing crimes against them) established his intent. Trial Chamber also notes that the victims were systematically selected by members of the Tutsi. When this issue came under consideration, we refer to the official appeal, the effect of his presence at the scene of the crimes and his exceptional ability to abet the committing crimes against members of the Tutsi (because of his influential position in society) will be highlighted. In addition, the branch considered impact the overall framework of acts done with the intention of destroying the Tutsi group, after the determination of the specific intent of appellant. "

\subsubsection{Case of Kayishema}

Rule of Trial Chamber judgment in the case of Kayishema was rendered (regardless of the Appeals Chamber disagreement) based on genocide performances at the Governor level (Governor of Kibo was Kayishema ), multiplicity of victims, planning and design of systematic massacres, excellent position accused and his speech and others. The court files also strongly stress general framework, the high position of accused (the minister) and "sufficient knowledge of the actions and statements during this time" have been part of broader framework of ethnic violence and killing and massacres in Rwanda. In the case of Simba, "the material perpetrators of the killings such as Simba given the scale of the killings were found to having had the intent to destroy, in whole or in part, the Tutsi group". However, the Court of Appeal described the defendant's conduct as abetting, the Trial Chamber sentenced him for participating in a joint criminal acts and to have genocide intention shared by all participants in the action, based the general framework of criminal behavior. However, in the case of Krstic, Criminal Court for the former Yugoslavia has carried out a more limited approach and appeal branch reversed the Trial Chamber judgment in the case as to his intent of genocide. Because according to appeals branch, only awareness of accused of planned genocide rather than his involvement can be established.

"Killings were planned, the number and nature of the forces involved in the conflict, the previously used coded language standard units transmit information on the killings, the scale of the executions, the same methods used in the killing, all indicate that the decision to kill all Bosnian Muslim military elderly men was in place".

What in terms of the objectives of this study is important is that in accordance with international legal proceedings, no one can be found that is found to have intent of genocide regardless of the broader framework of genocide and presence of genocide operations, namely general framework of criminal behavior plays key role in establishing intent of genocide. Of course, essentially special malice of genocide can be inferred from criminal behavior when accused involvement in genocide operations is established. In this regard, special courts have adopted an approach that has been investigated in accordance with the general framework of behavior and then the mental element of the accused in relation to the overall framework. Therefore, there are cases in which the intention of genocideis essentially inferred from the general framework of criminal behavior, and thus, more objective and independent and material manner of establishing the intention of the perpetrators is obtained. Otherwise, it seems impossible to prove bad intention in collective crimes like genocide (distinguishing their collective intention). Although general framework doesn't associated with state policy, the necessity of such a policy significantly reduce the distance between the criminal responsibility of the individual and aggravated state responsibility. Specific malice of accused as well as the state's fault as regards genocide must be established with 
a view to establishing the general framework of their criminal behavior.

It should also be noted that in order to facilitate verification of individual criminal responsibility for genocide, special courts apply in addition to the aforementioned method some modes of responsibility that require establishment of lower mental elements. In fact, as proof of intent of genocide is hard to provide due to the collective nature of this crime, specific methods that have been created specifically to deal with mass crimes and requires proof of the defendant's participation in the planned genocide with other perpetrators, and not necessarily intent of the destruction of the target group alone, can make it easier to establish the specific intent. Examples include the "abetting" or "joint criminal acts".

Moreover, sometimes it is stated that liability requires proof of intent whereby genocide commander and his knowledge of the crimes committed by his subordinates genocide will suffice. It is controversial due to the opposites international courts, criminal courts for Rwanda normally responsible persons pursuant to paragraphs 1 and 3 of article 6 of the statute genocide himself has condemned. According to court documents accused Ntagrura responsibility of the head and he was sentenced without proof of intent genocide. On the other hand, the Criminal Court for the former Yugoslavia at the beginning denied the possibility of invoking the responsibility of the head (where the commander or his subordinates had no intention genocide) was, in his recent vote, the liability requires proof of intent to ordain his genocide not, in his position is reviewed. So, people can be under the special modes without proof of intent genocide individual and with criminal intent inference from the general framework of criminal behavior (ie, the facts that can be checked to establish the fault of the state) was sentenced. This essential role in the overall framework of criminal behavior prove individual criminal responsibility and assume similar responsibility for the individual and the state genocide shows.

Moreover, sometimes it is stated that liability of commander doesn't require order of genocide and his knowledge of crimes committed by his subordinates will suffice. It is controversial due to the opposite views of international courts, criminal courts for Rwanda normally held people responsible pursuant to paragraphs 1 and 3 of article 6 of the statute of Genocide. In case of Ntagerura, defendant was found guilty based on theory of responsibility of the commander and he was sentenced without proof of intent of genocide. On the other hand, the Criminal Court for the former Yugoslavia that at the beginning denied the possibility of invoking the responsibility of the commander (where the commander or his subordinates had no intention of genocide), in his recent decision, revised his opinion by requiring that the liability of commander doesn't require proof of his intent of genocide, in his position is reviewed. So, people can be found guilty under the special modes without proof of individual intent of genocide and by inferring criminal intent from the general framework of criminal behavior (i.e., the facts that can be checked to establish the fault of the state). This shows essential role of the overall framework of criminal behavior in proving individual criminal responsibility and similarity of establishment of responsibility for the individual and the state genocide.

These show all that there no cases in which the accused was found to have the requisite genocidal intent, in the absence of a broader genocidal context. That is, the genocidal intent has always been established in connection to the existence of a genocidal campaign. Accordingly, the criminal context has has played a pivotal role in establishing the genocidal intent of the accused. In fact the dolus specialis of the defendant charged with genocide can be substancially inferred the general criminal context when it is shown that he or she took part in the genocidal campaign.

\section{Conclusion}

In this paper, the issue of The overlap between international criminal individual responsibility and the aggravated state responsibility was analyzed. Since the rules of international criminal law governing the criminal liability are limited to the people, and for this reason, the principle of "individual criminal responsibility" is among the fundamental principles of international criminal law, but given that some existing obligations in international law criminal fall within the obligations of the state (such as the obligation to prevent genocide), state cannot be absolved of any responsibility in this regard. That is why states are subject to a certain type of international responsibility called aggravated responsibility when it comes to violation of all-inclusive obligations. When international crimes (such as genocide) are committed by state or state agencies, only the trial of those responsible, designer or foreman of the crimes constitutes the trial of these crimes while the original and abstract will of people to realize their will is remains subject to impunity and enjoys the recognition of international responsibility of states and sovereign immunities.

In the draft plans of International Law Commission, particularly in the draft of the provisions related to the responsibility of state, international crime is distinguished from international misdemeanors, but the criminal responsibility of state assisting the international crime and criminal effects associated with them have not been 
addressed. Such failure to address these issues is due to sovereignty of state in international law on the one hand, and due to the fact that attribution of mens rea and material element of crime which requires application of physical force to the state is difficult.

Also imposition of punishment for crimes such as imprisonment or corporal punishments on such an abstract as state is not possible. Thus, attribution of international crime to the state, through the human factor, as agent or head of state and state is possible and brings about international criminal responsibility of the criminal and punishment as a result is of the practical aspects.

However, because of the resistance of state, the issue of criminal responsibility of the state has not been approved, since in international law, but the idea of recognizing the criminal responsibility of states was provided under Article 19 (former) of International Law Commission draft plan, and now it now known as the aggravated responsibility of in the practice of the international community.

In development of "code of crimes against the peace and security of mankind" that complements the international responsibility of the state plan, the international responsibility of states is divided into two separate legal regimes, "the responsibility for ordinary offences" and "the responsibility of gross human rights violations".

As for the prosecution of international crimes, doing justice can work as a deterrent against committing such crimes, or at least, it can make a record of the responsibility. Prosecuting and punishing international criminals could become a tool for establishing the rule of law into the public conscience. The establishment of the rule of law is of great importance, because one of the characteristics of the contemporary international relations after the Cold War is that non-international conflicts occur among people with ethnic backgrounds, different ethnic and religious groups within countries. One of the most effective ways to eliminate these disparities is the creation of citizens' trust in each other and their state, the establishment of a stable legal system and the rule of law.

Also, as for the presumptive rules, the observance of these rules is an international obligation. Rules that prohibit any inappropriate behavior that poses a threat to the state and people as well as the fundamental values of humanity. Among these prohibitions is prohibition of infringement of the territory of another state, slavery and genocide, which are considered by all state in Vienna conference as being prohibited.

New concepts of international responsibility of states ignore the classic rules of liability, including state immunity in the case of some specific regulations and all-inclusive rules of international law and new types of international responsibility of the state (such as aggravated responsibility) have been recognized, but what should be taken into consideration is that the state at the international level are solely responsible for actions or omissions which can be considered as that of a state.

The international criminal responsibility involves under international law only acts of the state organs and officials that brings about the international responsibility of the state.

In general, two factors of transition toward democratic state and humanitarian approaches in contemporary international law have gradually reduced the applicability of concept of immunity. With the development of international law in various fields, in particular, international criminal law and with the emergence of issues such as humanitarian intervention and the responsibility to protect, heads of state can no longer commit international crimes and escape justice by invoking the impunity.

Thus, although the heads of state and foreign ministers enjoy international criminal immunity, such immunity doesn't exclude their international criminal responsibility because, as mentioned above, the individual and state responsibility for a single act following primarily, individual criminal responsibility and exclusively, brings the aggravated state responsibility.

\section{References}

Ambos, K. (2002). Superior Responsibility. In A.Casseseet al (Eds.), The Rome Statute of the Internationl Criminal Court, A Commentary (Vol. I). Oxford, oxford university Press. http://dx.doi.org/10.2139/ssrn.1972189

Bassiouni, M. C. (1999). Crimes Against Humanity. International Criminal Law.

Code of offences Against the peace and security of mankind.Extract From The Yearbook of The ILC1950,VOL(II).

Fletcher, G. P., \& Ohlin, J. D. (2005). 'Reclaiming fundamental principles of criminal law in the darfur case, 3 $\mathrm{jICj}$.

Fournet, C. (2013). Genocide and Crimes Against Humanity Misconceptions and confusion in French Law and 
Practice (1st ed.).

ICTR, Prosecutor V. Akayesu, TC, judgment, 2 september 1998, paras.78-129.

ICTR, prosecutor V. Baghilishema, TC, judgment, 7 june 2001, para. 63.

ICTR, prosecutor V. karemera et al, AC, Decision on prosecutor's Interlocutory Appeal.

ICTR, prosecutor V. karemera et al. AC, Decision on proseutor's Interlocutory Appeal of Decision on judicialNotice, 16 June 2006.

ICTR, prosecutor V. kayishema and Ruzindana, AC, judgment, 1 June 2001, para. 148.

ICTR, prosecutor V. kayishema and Ruzindana, TC, judgment, 21 May 1999, paras. 31-54.

ICTR, prosecutor V. Muhimana, TC, judgment, 28 April 2005.

ICTR, Prosecutor V. Musema, TC, Judgment, 27 January 2000, paras. 166-167.

ICTR, prosecutor V. Nahimana et al. (Media Trial), 3 December 2003.

ICTR, prosecutor V. Nahimana etal, TC, judgment, 3 December 2003. ICTR, prosecutor V. kamunanda, AC, judgment, 19 september 2005.

ICTR, prosecutor V. Ntagerura et al, TC, Judgment, 25 February 2004, para. 654.

ICTR, prosecutor V. Rutaganda, AC, Judgment, 26 May 2003, paras. 529-530. ICTR, prosecutor V. Ndindabahizi, TC, judgment, 15 July 2004.

ICTR, Prosecutor V. Rutaganda, TC, Judgment, 6 December 1999, para.167.

ICTR, prosecutor V. simba, TC, Judgment, 13 December 2005.

ICTY, proseator V. krstic, TC, judgment, 2 August 2001, para. 572.

ICTY, prosecutor V. Blagovic and jokic, TC, judgment, 17 january 2005, paras.785-786.

ICTY, prosecutor V. Brdanin, TC, judgment, 1 september 2004, para.707.

ICTY, prosecutor V. jelisic, TC, judgment, 14 December 1999, para.100. ICTY, prosecutor V. krajisnik, TC, Decision on prosecution Motions for judicial Notice of Adjudicated facts and for Admission of writtenstatements of witness pursuant to Rule 92 bis, 28 Fbruary 2003.

ICTY, prosecutor V. Karadzic and Mladic, TC, Review of The indictments prusuaut to Rule 61 of The Rules of procedure and Evidence, 11 july 1996, para. 94.

ICTY, prosecutor V. krstic, AC, Judgment, 19 April 2004, para. 34.

ICTY, prosecutor V. krstic, TC, judgment, 2 August 2001, para. 663.

ICTY, prosecutor V. stakic, TC, judgment, 31 July 2003, para. 559.

ICTY, prosecutor V. stakic, TC, judgment, 31 July 2003, para.554. ICTY, prosecutor V. krstic, TC, judgment, 17 january 2005, para. 786 .

Kittichaisaree, K. (2001). International Criminal Law. Oxford, oxford university press.

Provost, R., \& Akhavan, P. (2011). Confronting Genocide. Springer. http://dx.doi.org/10.1007/978-90-481-9840-5

Report of the International commission of Inquiry on Darfur to united Nations secretary - General pursuant tosecurity council Resolution 1594 of 18 september 2004.

Schabas, W. A. (2009). Genocide In International Law (The Crime of Crimes). Cambridge University Press, Second Edition.

ZiaeeBigdeli, M. R. (2001). The laws of war (2nd ed.). AllamehTabatabaie University Press.

\section{Copyrights}

Copyright for this articleis retained by the author(s), with first publication rights granted to the journal.

This is an open-access article distributed under the terms and conditions of the CreativeCommons Attribution license (http://creativecommons.org/licenses/by/3.0/). 